\title{
HOW EXCESSIVE ARE EXTERNAL IMBALANCES IN SELECTED TRANSITION COUNTRIES?
}

\author{
Aleksander Aristovnik *, Stanka Setnikar-Cankar
}

\begin{abstract}
:
This article examines the main current account balance determinants in order to assess the potential excessiveness of current account deficits in selected transition countries. For this purpose, dynamic panel-regression techniques are used to characterise the properties of current account variations across the transition regions. The results are chiefly consistent with the theoretical and previous empirical analysis, indicating a moderate level of current account deficits persistency and negative effects of economic growth, real appreciation and worsening of terms of trade on the external balances. Furthermore, the validity of the stages of development hypothesis and twin deficit hypothesis, as well as the significance of demographic factors is confirmed in the regions. Finally, the results suggest that most transition countries are justified in running relatively high current account deficits.
\end{abstract}

Keywords: transition, current account deficits, excessiveness, determinants, dynamic panel data

JEL Classification: C33, F32

\section{Introduction}

The current account balance is an important indicator of a transition economy's performance and it plays several roles in policymakers' analyses of economic developments. First, its significance stems from the fact that the current account balance, reflecting the saving-investment ratio, is closely related to the status of the fiscal balance and private savings which are key factors of economic growth. Second, a country's balance on the current account is the difference between exports

*) University of Ljubljana, Faculty of Administration, Department of Economics and Public Sector Management, Gosarjeva ul. 5, 1000 Ljubljana, Slovenia (aleksander.aristovnik@fu.uni-lj.si).

The authors are grateful to anonymous referees, whose comments helped them in improving the content and exposition of the paper. Earlier versions of the paper was presented at International conference: Economic Recovery and Reforms' in Bangkok, Thailand, and at 'International Conference: Transitional Impacts and the EU Enlargement Complexity' in Mostar, Bosnia and Herzegovina. Comments from conference participants led to the current version of the paper. The paper is also part of Aleksander Aristovnik's Ph.D. research titled 'Current Account Sustainability in Selected Transition Countries'. Any remaining errors and ambiguities are their responsibility. 
and imports, reflecting the totality of domestic residents' transactions with foreigners in the markets for goods and services. Third, since the current account balance determines the evolution over time of a country's stock of net claims on (or liabilities to) the rest of the world, it reflects the intertemporal decisions of (domestic and foreign) residents. Consequently, policymakers endeavor to explain current account balance movements, to assess their sustainable (and/or excessive) levels and to seek to induce changes to the balance through policy measures.

The growth of current account deficits in transition countries has raised questions about their potential excessiveness and concerns regarding the potential impact a rapid and disorderly correction of these imbalances might have. Roubini and Wachtel (1999) argued that the current account deficits seen in transition countries reflect two important aspects. On the one hand, these deficits reflect the success of structural changes that have enabled capital and investment inflows and have opened up prospects of fast economic growth. On the other hand, from another perspective current account deficits frequently reflect mismanaged transition processes featuring unsustainable imbalances that are potentially a source of a value or a balance of payments crisis (e.g. Czech Republic (1997), Russia (1998)). In line with this, strong demands have emerged to assess the 'excessiveness' of the external position of the so far mainly neglected transition countries.

Practically all transition countries have been involved in their own catching-up processes which includes financing a huge amount of productive investment without endangering their external sustainability as far as their current account positions and external debt are concerned. In fact, these countries suffer from relatively low and even stagnant saving rates. Hence, to close the gap they need to turn to foreign savings which has generally induced the high and even growing current account deficits of the last decade. In this respect, the problem of external imbalances is particularly important for the Central and Eastern European (CEE) countries which joined the EU in May 2004 and have already expressed their desire to adopt the euro as soon as possible. Consequently, for the new (and other prospective) members of the EU (e.g. Southern and Eastern Europe (SEE)) a trade-off has emerged between the catching-up process and meeting the qualitative current account Maastricht criteria. ${ }^{1)}$

The approach taken in the article is to view the current account positions as a reflection of their saving and investment balances and, thus, to characterize the fundamental determinants of their levels in a short- to medium-term perspective. Even though such an approach is essentially empirical, it relies primarily on various theoretical models for identifying these fundamental determinants and interpreting their impact on the current account levels. Accordingly, the article primarily focuses on the (short-term) determinants of current account dynamics in transition countries. ${ }^{2)}$

\footnotetext{
1) Article 121 (Treaty of the European Union, 1992) states that among other (qualitative) criteria »the situation and the evolution of the balance of current payments « of the applicant countries have to be examined before they enter the euro area. Recently, an important step towards the euro area was taken by Estonia, Lithuania and Slovenia which joined the ERM II with effect from 28 June 2004 (ECB, 2004) and by Latvia joining the ERM II with effect from 2 May 2005.

2) The short-term, cyclical influence of selected current account determinants could be considered by including their average values. However, due to the relatively small number of observations (countries) in the sample the long-term influence could not be assessed.
} 
In this respect, the empirical analysis expands and builds upon some previous similar attempts for transition countries (see Roubini and Wachtel, 1999, Doisy and Hervé, 2003, Zanghieri, 2004, Herrmann and Jochem, 2005 etc.) in the following important ways:

a) annual data for 26 (or 14) transition countries in the 1992-2003 period are included;

b) a wide number of (internal and external) macroeconomic and other variables suggested by theoretical and empirical literature is used;

c) time-series cross-sectional (panel) data with the inclusion of a variety of modern econometric techniques are employed; and

d) the potential ex post excessiveness of current account deficits in transition countries in the $2000-03$ period is assessed.

The article is organized as follows. The next section briefly presents current account balance trends and developments in transition countries in the 1992-2003 period. Section 3 presents some theoretical considerations and empirical evidence on the current account balance and its excessiveness, which have so far mainly been concentrated on developed economies. Section 4 then describes the empirical methodology, assumptions, data and empirical results of the determinants and assesses (potential) excessive current account positions for the selected transition countries. The final section provides some concluding remarks.

\section{Current Account Developments In Transition Countries}

An overview of the current account balance in transition countries shows that, with the exception of Russia - a major commodity exporter, the opening up to external trade has been accompanied by significant current account deficits (see Table 1 in Appendix B). In CEE the current account balances were not problematic with even a moderate positive balance as a share of GDP up until 1994 (averaging around 1 per cent of GDP), reflecting contractions in domestic demand, real exchange rate undervaluations and external financing constraints. Afterwards, a significant current account deficit deterioration was noticed in the region, peaking at almost 7 per cent of GDP in 1998 on average (e.g. Lithuania (11.7), Latvia (10.7) and Slovakia (9.6)), mostly as a result of growing imports of both consumption and investment goods. Moreover, the gradual growth of the current account deficit in the CEE region reflects a combination of long-term growth and structural factors, external shocks and domestic policies. More precisely, the deterioration of current accounts in the region was the result of the growth of merchandise trade deficits, downward trends in the service balance, rising indebtedness and profit repatriation as well as the consequence of the continuous real appreciation of domestic currency in most of the cases examined. ${ }^{3)}$

3) In transition countries a large part of real appreciation accounts for the real appreciation that reflects productivity gains in the tradable sector (due to the Balassa-Samuelson (B-S) effect) This trend is commonly the case in fast growing economies like transition countries where the catch-up process is mainly driven by an increasingly productive tradable sector. For example, Coricelli and Jazbec (2001) estimated that B-S effects in (19 selected) transition countries were between 0.7-1.2 per cent p.a. over the 1990-1998 period. 
Figure 1

Average Current Account Balances (CA), Investments (I) and Savings (S) in Transition Regions (in \% of GDP; unweighted average)

CEE
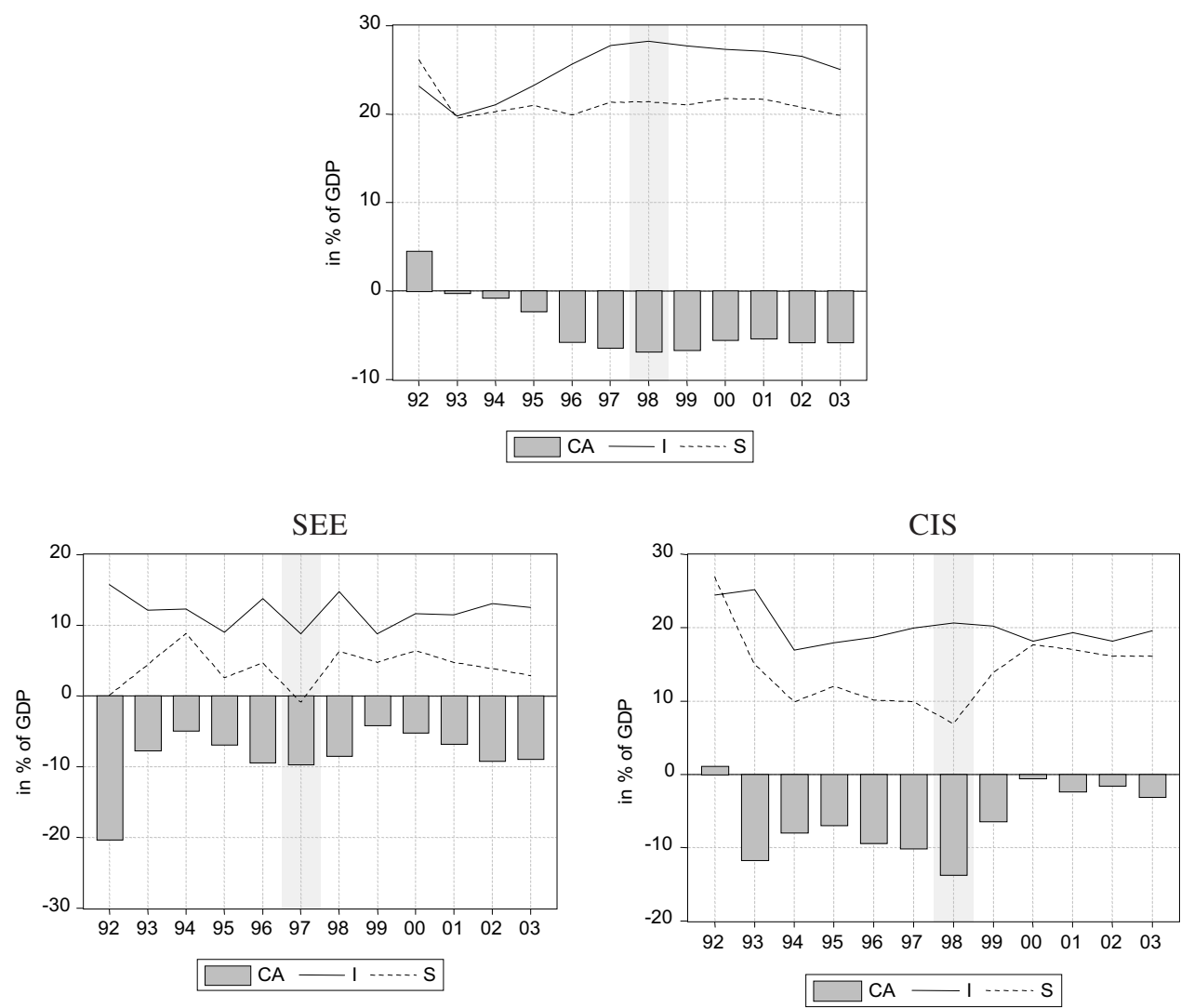

Sources: WDI (2004), EIU (2004), EBRD (2004), author's calculations.

Similar but even more intensive current account deficit dynamics were seen in the Commonwealth of Independent States (CIS) region by achieving the top average current account deficit at a significantly higher level (13.7 per cent of GDP) than the CEE region in 1998. The major contributors to such a huge deterioration of the current account balance were some countries in the region with current account deficits above 20 per cent of GDP (e.g. Turkmenistan (37.4), Azerbaijan (30.7), etc.). Several factors contributed to this. First, many countries in the region experienced large losses in their terms of trade as prices for energy imports from the former Council for Mutual Economic Assistance's (CMEA) trading partners moved to market-determined levels. Second, these countries ran high negative fiscal imbalances as the authorities tried to absorb the revenue and expenditure pressure associated with sharp falls in national income and fiscal restructuring (see Table 1 in Appendix B). Third, as a result of slow progress in building a competitive and diversified export sector trade liberalization mainly stimulated imports of consumer 
goods and services. As a response to the Russian crisis the average current account deficits narrowed in the group. However, in many cases the deficits remained high - around or even above 10 per cent of GDP (Azerbaijan (15.9), Armenia (8.1), etc.) on average in the 2001-2003 period. On the other hand, the SEE region achieved the highest average current account deficit with around 20 per cent of GDP in 1992 due to the enormous deficit in Albania (68.5 per cent). Later, these huge external imbalances improved significantly. However, at the beginning of the second half of the 1990s and in the early years of the 21 st century they again deteriorated, ultimately raising the question about their sustainability and excessiveness. Eventually, the average current account deficit was 8.2 per cent of GDP in the 2001-2003 period in comparison to the previous three years when it averaged out at 5.9 per cent of GDP (see Figure 1).

\section{Views on the Current Account Balance and Its Excessiveness}

\subsection{Do Current Account Deficits Matter?}

In his comprehensive review Edwards (2001) describes economists' evolving views regarding the nature and consequences of current account deficits. The attitude has changed from 'the current account matters' to 'the current account deficit does not matter as long as the public sector is in balance', then to 'the current account deficit may matter'. In fact, in the 1970s this elastic approach to the current account was placed on the backburner and attention was switched to the intertemporal properties of current account deficits. In terms of national accounting, the current account is simply the difference between national savings and investment. Since both savings and investment are inherently intertemporal phenomena, e.g. savings with respect to the lifetime of individuals and investment with respect to the expected future return on investment, the same must also hold for the current account.

In this respect, Obstfeld and Rogoff (1996) provided an extensive review of modern models of the current account that assume intertemporal optimization on behalf of consumers and firms. In this type of model (assuming a constant interest rate), consumption smoothing across periods is one of the fundamental drivers of the current account. According to the intertemporal approach, if output falls below its permanent value there will be a higher current account deficit. Similarly, if investment increases above its permanent value the current account deficit will grow. The reason for this is that new investment projects will be partially financed by an increase in foreign borrowing, thus generating a bigger current account deficit. Likewise, increased government consumption will result in a higher current account deficit. If the constant world interest rate assumption is relaxed, a country's net foreign asset position and the level of the world interest rate will fundamentally affect the current account deficit. Accordingly, if a country is a net foreign debtor, and the world interest rate exceeds its permanent level, the current account deficit will be higher (Miller, 2002).

During the last three decades most financial crises have highlighted the part played by large current account deficits in the run-up to crisis episodes. Consequently, the concept of a sustainable (and excessive) current account deficit became an important theoretical, political and economic issue. In this sense, Corsetti et al. (1998) 
concluded that, on the whole, those countries hit hardest by currency crises were those running persistent current account deficits throughout the 1990s. ${ }^{4)}$ This result is confirmed by Radelet and Sachs (2000), Kamin et al. (2001) and Edwards (2004), whereby Edwards shows that the probability of experiencing abrupt current account reversals is closely linked to the size of current account deficits. Accordingly, although this is not a universal truth, the conventional wisdom is that current account deficits above 5 per cent of GDP generally represent a problem, especially if funded through short-term borrowing. However, because of the lasting improvement in capital market access, the persistent enhancement of the terms of trade and productivity growth seen in transition countries can, as predicted by the intertemporal models, finance moderate current account deficits on an ongoing basis. Nevertheless, Edwards (2001) supported the relevancy of current account imbalances as there is strong evidence that large current account deficits should be a cause for concern of economic policy.

\subsection{Solvency, Sustainability and Excessive Current Account Imbalances}

According to Milesi-Ferretti and Razin (1996, hereafter 'MFR'), three different yet interrelated concepts can be distinguished: an economy's solvency, current account sustainability and current account deficit excessiveness. In fact, the three concepts of current account deficits imply an increasing order of restrictiveness. First, an economy is treated as solvent if the present discounted value of the future trade surplus is equal to the current external indebtedness. Ultimately, such a definition is difficult to apply since it relies on future events/policy decisions without imposing any 'structure' on them. Second, a narrower definition of solvency brings us to a more widespread idea, i.e. the definition of sustainability. A current account is sustainable if the continuation of the current government policy stance and/or of present private sector behavior will not entail a need for a 'drastic' policy shift or a balance of payments (currency) crisis. ${ }^{5)}$ Finally, an unsustainable deficit should be distinguished from an excessive one, i.e. a deficit which is too large to be explained in the terms of any given model of consumption, investment and production. In fact, the notion of excessive current account deficits is based of deviations from an 'optimal' benchmark, which can be calculated under some strict assumptions such as perfect capital mobility and efficient financial markets. Since our primary goal is to assess the potential excessiveness of current account balances, we focus particularly on the latter concept.

Three main approaches to the empirical implementation of the concept of excessiveness have recently been used. The first approach relies on a structural estimation of the model, focusing in particular on estimated responses to various types of productivity shocks (permanent, global, etc.), as well as other shocks (see Glick and Rogoff, 1995 and Razin, 1995). While the presence of investment adjustment costs

\footnotetext{
4) Nevertheless, this does not imply that a large deficit always leads to a crisis, nor that a crisis can only occur if a large current account deficit is present (Summers, 2000).

5) A similar notion of current account sustainability has been applied by many authors such as Obstfeld and Rogoff (2000), Holman (2001), Megarbane (2002) and Zanghieri (2004).
} 
and stochastic productivity lend more realism to the model, the data requirements for the model's estimation have so far limited its applications to a sample of developed countries (see, for example, Iscan, 2000, Perez de Gracia and Cunado, 2001, etc.).

The second approach emphasizes the consumption-smoothing role of the current account, where the current account deficit reflects expected increases in future net output. The basic idea is based on the application of Campbell's (1987) methodology for testing the permanent income theory of consumption, and is consistent in the estimation of a simple VAR model. The model's implication is that the current account balance should incorporate all available information for predicting future changes in net output. Accordingly, a predicted current account path is constructed and can be compared with the actual one in order to gauge the excessiveness of external imbalances (see, for example, Adedeji, 2001, Nason and Rogers, 2003, etc.).

The third one is based on saving-investments balance determinants as suggested by the theoretical literature (including intertemporal approach literature). On the basis of these determinants, fitted values of the model are compared to the actual levels of the current account, presenting a benchmark of excessiveness. This approach is closely related to the intertemporal approach to the current account where the current account imbalance is a result of an intertemporal optimization with the objective of optimally distributing consumption over time (consumption smoothing) (see Sachs, 1981, Obstfeld, 1982 and Svensson and Razin, 1983). This approach has recently been widely applied (see, for example, Isard et al., 2001, Doisy and Hervé, 2003 and Bussière et al., 2004) and indicates the special importance of demographics, stage of development and fiscal policy (in a long-term period) and the real exchange rate, terms of trade as well as world economy conditions (economic growth and interest rate) (in a short-term period). In fact, the article builds upon the work of the authors cited above and, in particular, generalizes the work of Doisy and Hervé (2003) and Bussière et al. (2004) by extending the analysis to practically all transition countries for a longer time span and by exploring a wider range of specifications.

\section{The Empirical Framework}

\subsection{Empirical Methodology}

The initial aim of the empirical research is to identify the main (short-term) determinants of current account deficits in the transition region in the 1992-2003 period. Following previous theoretical and empirical studies of Debelle and Faruqee (1996), Calderon et al. (2002), Chinn and Prasad (2003), Doisy and Hervé (2003), Bussière et al. (2004) and Zanghieri (2004) we estimate a model which may be expressed in the following general form:

$$
C A_{i t}=\alpha_{i}+\gamma_{t}+\beta C A_{i t-1}+\lambda \mathbf{x}_{i t}+u_{i}+\varepsilon_{i t}
$$

where the dependent variable is current account balance $(C A)$ (negative values indicate a deficit) for the $i$-th unit at time $t$ and the vector of independent variables $\left(\mathbf{x}_{i}\right)$ includes real GDP growth $(G D P G)$, relative income (RELY), general government budget balance $(G O V B)$, openness $(O P E N)$, external debt $(E X T D E B T)$ and GDP growth of the EU-15 (GDP-EU) (for the extended-form model - model A); and 
general government budget balance (GGBB), relative dependency (RELDEP), real effective exchange rate (REER) and terms of trade (TOT) (for the reduced-form model - model $B$ ). The vector $\beta$ and $\lambda$ is a vector of coefficients $\gamma_{t}$ denotes timespecific effects which are peculiar to a particular period but constant for all countries and $u_{i}$ and $\varepsilon_{i t}$ denote a two-part error term. The first component of the latter, $u_{i}$, captures unobserved and time-invariant country effects that influence the current account while $\varepsilon_{i t}$ captures the residual errors. The term $\alpha_{i}$ represents the effects of those variables peculiar to the $i$-th individual country in more or less the same fashion over time. In our case, the dummy vector represents 26 (model A) or 14 (mo$\operatorname{del} B$ ) individual countries entering the panel data.

As heterogeneity is the main characteristics of the countries under consideration, other specifications might be preferred to a simple OLS specification in our analysis. In fact, in the case of transition countries this argument is plausible once differences like macroeconomic conditions and structural reforms are taken into account. Moreover, since panel data typically exhibit group-wise heteroscedastic, contemporaneously and serially correlated residuals, we must take into account the existence of a non-spherical error structure. Therefore, we extended the benchmark OLS model by using special techniques, i.e. the Parks-Kmenta method and the Beck-Katz PCSE method.

The Parks-Kmenta method performs the estimation by using Generalized Least Squares (GLS) and consists of applying two sequential transformations on the estimated model. The first transformation removes the serial correlation, while second simultaneously corrects for contemporaneous correlation and heteroscedasticity (see Beck and Katz, 1996). The Parks-Kmenta method was revised by Beck and Katz (1996). They confirm that GLS have optimal properties for panel data but remark that GLS can only be used when the variance-covariance matrix of errors is known. Otherwise, it should be estimated from the sample implying the use of Feasible Generalized Least Squares (FGLS) instead of GLS. On the other hand, Beck and Katz (1996) proposed a less complex method, retaining OLS parameter estimates (consistent but inefficient) and replacing OLS standard errors with panel-corrected standard errors (PCSE). Since the sample of the models ( $A$ and $B$ ) contains more countries than annual observations per country, we propose using ordinary least squares with panel corrected standard errors (OLS-PCSE). Nevertheless, we present the estimations based on both methods (FGLS and OLS-PCSE), including country and time-fixed effects.

However, since $C A_{i t}$ is a function of $u_{i}, C A_{i t-1}$ will also be a function of $u_{i}$ thereby rendering OLS biased and inconsistent. Further, $u_{i}$ is likely to be correlated with at least one or more of the RHS variables. Therefore, we use fixed (FEM or sometimes called a Least Square Dummy Variable - LSDV) and random effects (REM) estimators adding both country and time effects. Indeed, the Breusch-Pagan LM test confirms the appropriateness of the models based on panel data. Moreover, Hausman's test indicates that for both models the fixed-effect model (LSDV) provides a better specification. But these approaches do not correct the biases due to the presence of the lagged depended variable. ${ }^{6}$ Thus, in order to obtain consistent and ef-

6) In particular, the LSDV estimator introduces a correlation between the transformed $\beta C A i_{t-1}$ and transformed error $\varepsilon_{i t}$ even when $\varepsilon_{i t}$ is not serially correlated. The LSDV estimator is thus biased while it will be consistent for a longer panel (i.e. larger T). 
ficient estimates of the model we employed the generalized method of moments GMM-IV of Arellano and Bond (1991). Initially, a first difference transformation of equation 1 is used to do away with the correlation between $u_{i}$ and $C A_{i t-1}$ and $\mathbf{x}_{i t}$ :

$$
C A_{i t}-C A_{i t-1}=\beta\left(C A_{i t-1}-C A_{i t-2}\right)+\gamma\left(\mathbf{x}_{i t}-\mathbf{x}_{i t-1}\right)+\left(\varepsilon_{i t}-\varepsilon_{i t-1}\right)
$$

Next, the lagged dependent variable $\left(C A_{i t-1}-C A_{i t-2}\right)$ is instrumented for. As long as $\varepsilon_{i t}$ are not serially correlated, a natural choice for an instrument is $C A_{i t-2}$. Additional instruments can be obtained by utilizing the orthogonality conditions existing between the various available lagged $C A_{i t}$ and $\varepsilon_{i t}$. The consistency of the GMM estimator depends on whether lagged values of the explanatory variables are valid instruments in the current account balance regression. We address this issue by considering two specification tests suggested by Arellano and Bond (1991) and Arellano and Bover (1995). The first is a Sargan test of over-identifying restrictions which tests the overall validity of the instruments by analyzing the sample along with the momentary conditions used in the estimation process. Failure to reject the null hypothesis lends support to the model. The second test examines the hypothesis that the error term $\varepsilon_{i t}$ is not serially correlated. We test whether the differenced error term is first-, second-, and third-order serially correlated. If the test confirms the null hypothesis of the absence of a first-order serial correlation and rejects it of the second-order, then we conclude that the original error term is serially uncorrelated and use the corresponding momentary conditions.

Since all alternatives to the LSDV estimators are not without their disadvantages, we estimate all four estimators. Indeed, while these estimators have superior asymptotic properties they are less precise than the LSDV (see Kiviet, 1995). Bond (2002) also emphasizes that alternatives to the LSDV estimator may be subject to large sample biases where the instruments are weak. In addition, Chen et al. (2005) suggest that the use of the OLS-PCSE method is most appropriate if we are concentrating on testing hypotheses and to use the FGLS method if our prime interest is accurate coefficient estimates. In what follows, we estimate the models using the LSDV, FGLS, OLS-PCSE and GMM-IV estimators and use all our estimators and base the further analysis on the joint evidence. The results of the tests and partial regression coefficient are presented in Tables 1 and 2.

\subsection{Data}

We estimate models ( $A$ and $B$ ) on the basis of pooled cross-sectional and time-series (panel) data for transition countries in the 1992-2003 period. The data set comes from the EBRD Transition Reports, the Economist Intelligence Unit (EIU) and World Development Indicators (WDI) and covers the 26 transition countries, i.e. eight CEE, six SEE and twelve CIS countries. Our estimates are based on unbalanced panel data while data for some countries included in the sample were unavailable for the whole period. The dependent variable is a current account balance $(C A)$, expressed as a ratio to GDP (negative values indicate a deficit). Independent variables (for model $A$ ) are: a) the lagged $C A$; b) growth rate of gross domestic product, where the real economic growth is taken $(G D P G)$; c) income per capita relative to income per capita in the EU-15 (RELY); d) the general government budget balance as measured by the general government budget balance $(G O V B)$; e) open- 
ness, expressed as the ratio of goods and services trade to GDP (OPEN); f) external debt, measured as external debt as a percentage of GDP (EXTDEBT); and, g) real economic growth in the EU-15 (GDPG-EU). Moreover, independent variables (for model $B$ ) are (besides GOVB): a) age dependency ratio, defined as the ratio of the number of people younger than 15 and older than 65 years over the total population relative to sample average $(R E L D E P)$; b) the real effective exchange rate $(R E E R)$ is expressed as an index with the base year 1997; an increase in the index denotes real appreciation; and, c) terms of trade (TOT) is considered as the ratio of export and import prices with the base year 1996. ${ }^{7)}$ Variable descriptions and data sources as well as the countries included in the sample are presented in Appendix A. In addition, summary statistics of the variables are shown in Table 3 in Appendix B.

\subsection{Empirical Results}

The results of the empirical analyses of (short-term) current account determinants of transition countries by using the LDSV, FGLS, OLS-PCSE and GMM-IV estimators for both models (A and B) are presented in Tables 1 and $2{ }^{8}{ }^{8}$ The estimates of partial regression coefficients are generally in line with the theoretical and previous empirical analysis. Since we estimate dynamic panel data model, the most appropriate technique is the GMM-IV estimator. However, in order to ensure the robustness of the estimates the estimators of other econometric techniques are also employed.

Persistency: Empirical analysis shows that the lagged current account balance (as a ratio to GDP) has a positive and statistically significant effect on the current account. The size of this partial regression coefficient $(0.19-0.33)$ reveals the modest persistence of transitory shocks, implying that the persistency of these shocks on the current account is up to one year (similar to heavily-indebted countries as found by Calderon et al., 2002). The results reflect a relatively moderate current account adjustment process, which could be influenced by foreign creditors as well as by decisions of the private sector. Indeed, it captures the partial adjustment of the current account and can be explained by decisions on private sector net savings which are influenced by the relatively high persistency of private consumption in the region. The alternative estimators yield approximately similar results regarding the size and significance of the lagged current account balance. Moreover, such results are similar to the results of Bussière et al. (2004), Zanghieri (2004), and Herrmann and Jochem (2005).

\footnotetext{
7) Additional variables, like financial deepening (ratio between M2 and GDP) and foreign real interest rate (LIBOR) do not improve the model since they express theoretically expected, but statistically insignificant results.
}

8) Since there is no high pair-wise correlation among explanatory variables (see Tables 4 and 5 in Appendix B) and variance inflation factors (VIF) are within the permitted borders, multicollinearity seems not to be a problem in our analyses. 


\section{Domestic Economic Conditions}

Real Economic Growth: An increase in the domestic output growth rate (GDPG) has the effect of expanding the current account deficit. The result is consistent with theoretical expectations that domestic economic growth accelerates demand for foreign goods and services and consequently deteriorates the current account balance (see Abel and Bernanke, 2001 and Gandolfo, 2004). A one-percentage point rise in GDP growth leads to about 0.54 of a percentage point rise in the current account deficit. Although a rise in domestic output growth may be associated with a greater savings rate, it seems that its correlation with the investment rate is somewhat stronger, thus leading to a worsening of the current account balance. ${ }^{9)}$ When endogeneity is not controlled for, a smaller coefficient on growth may be the result of negative reverse causality. This is consistent with the notion that a larger current account deficit brings about a poorer growth performance in the region. In fact, these results are in line with the findings of Zanghieri (2004) for selected transition countries, Calderon et al. (2002) for developing countries, Chinn and Prasad (2003) for developed countries and the IMF (2005) for emerging market economies.

Relative income: We find a positive association between relative income (RELY) and the current account balance. A per capita income of 10 per cent below the average of the EU-15 lowers the current account by approximately 0.64 of a percentage point. The rationale is that less developed countries are assumed to grow faster than the average and are thus borrowing against future income (consistent with the stages of development hypothesis). Indeed, the consumption smoothing process, lack of physical capital and relatively large educated labour force provide an important explanation for current account deficits that reflect the catching-up process seen in the region (Duczynski, 2005). This result is similar to the findings of Calderon et al. (2002), Chinn et al. (2003), Zanghieri (2004) and Herrmann and Jochem (2005).

Public balance: The government budget balance (GOVB) appears to be positively statistically significant in relation to the current account balance. A one-percentage point rise in the government budget balance leads to about $0.30-0.40$ of a percentage point rise in the current account balance. The estimated coefficient for GOVB suggests that a one-percentage point increase in the government budget deficit is associated on average with approximately two-thirds of a percentage point increase in the current-account-deficit-to-GDP ratio, with all other things being equal. Such results imply moderate liquidity constraints and the inelasticity of domestic (private) consumption and are similar to the results of Roubinni (1988), Chinn and Prasad (2003), Zanghieri (2004), Herrmann and Jochem (2005). The significant positive relationship between the government budget balance and the current account provide some evidence in favour of the so-called twin deficits hypothesis, but we could not reject the inter-temporal approach due to the short time period involved and disregarding the distinction between temporal and permanent shocks.

9) The results confirm the theory of real business cycles (see Kydland and Prescott, 1990) in that part where it advocates the dominance of investments over savings when the economy grows. In addition, the results are in line with new Keynesian macroeconomics, which predicts anti-cyclical effects of the current account balance (see Mankiw, 2003). 
Table 1

Estimates of Regression Coefficients for Model (A) - 26 Transition Countries, (19922003) (Dependent Variable: CA)

\begin{tabular}{|c|c|c|c|c|}
\hline Explanatory Variables & $L S D V$ & $F G L S$ & OLS-PCSE & GMM-IV \\
\hline \multicolumn{5}{|l|}{ Persistency } \\
\hline$C A_{-I}$ & $\begin{array}{c}0.349 \\
(0.051 ; 0.00)\end{array}$ & $\begin{array}{c}0.438 \\
(0.04 ; 0.00)\end{array}$ & $\begin{array}{c}0.432 \\
(0.101 ; 0.00)\end{array}$ & $\begin{array}{c}0.330 \\
(0.065 ; 0.00)\end{array}$ \\
\hline \multicolumn{5}{|c|}{ Internal Economic Conditions } \\
\hline$G D P G$ & $\begin{array}{c}-0.158 \\
(0.053 ; 0.00)\end{array}$ & $\begin{array}{c}-0.155 \\
(0.045 ; 0.00)\end{array}$ & $\begin{array}{c}-0.197 \\
(0.080 ; 0.01)\end{array}$ & $\begin{array}{c}-0.544 \\
(0.233 ; 0.02)\end{array}$ \\
\hline RELY (in logs) & $\begin{array}{c}0.066 \\
(0.038 ; 0.08)\end{array}$ & $\begin{array}{c}0.004 \\
(0.004 ; 0.35)\end{array}$ & $\begin{array}{c}0.012 \\
(0.007 ; 0.08)\end{array}$ & $\begin{array}{c}0.064 \\
(0.021 ; 0.00)\end{array}$ \\
\hline GOVB & $\begin{array}{c}0.727 \\
(0.143 ; 0.00)\end{array}$ & $\begin{array}{c}0.653 \\
(0.097 ; 0.00)\end{array}$ & $\begin{array}{c}0.608 \\
(0.177 ; 0.00)\end{array}$ & $\begin{array}{c}0.391 \\
(0.199 ; 0.05)\end{array}$ \\
\hline \multicolumn{5}{|l|}{ External Sector } \\
\hline OPEN & $\begin{array}{c}-0.019 \\
(0.023 ; 0.38)\end{array}$ & $\begin{array}{c}-0.027 \\
(0.008 ; 0.00)\end{array}$ & $\begin{array}{c}-0.038 \\
(0.011 ; 0.00)\end{array}$ & $\begin{array}{c}-0.011 \\
(0.030 ; 0.70)\end{array}$ \\
\hline$E X T D E B T_{-I}$ & $\begin{array}{c}0.043 \\
(0.018 ; 0.02)\end{array}$ & $\begin{array}{c}0.020 \\
(0.011 ; 0.06)\end{array}$ & $\begin{array}{c}0.038 \\
(0.016 ; 0.02)\end{array}$ & $\begin{array}{c}0.024 \\
(0.036 ; 0.50)\end{array}$ \\
\hline \multicolumn{5}{|c|}{ Evolution of the World Economy } \\
\hline GDPG-EU & $\begin{array}{c}0.750 \\
(0.343 ; 0.03)\end{array}$ & $\begin{array}{c}0.388 \\
(0.208 ; 0.06)\end{array}$ & $\begin{array}{c}0.650 \\
(0.500 ; 0.19)\end{array}$ & $\begin{array}{c}1.243 \\
(0.605 ; 0.04)\end{array}$ \\
\hline Adj. $\mathbf{R}^{2}$ & 0.357 & & 0.457 & \\
\hline No. of Countries & 26 & 26 & 26 & 26 \\
\hline No. of obs. & 255 & 255 & 255 & 207 \\
\hline $\begin{array}{l}\text { Hausman test }\left(\mathbf{x}^{2}\right) \\
\text { (p) }\end{array}$ & \multicolumn{3}{|c|}{$\begin{array}{c}82.6 \\
(0.00)\end{array}$} & \\
\hline $\begin{array}{l}\text { Modified Wald test }\left(\mathbf{x}^{2}\right) \\
(\mathrm{p})\end{array}$ & \multicolumn{3}{|c|}{$\begin{array}{c}2249.48 \\
(0.00)\end{array}$} & \\
\hline $\begin{array}{l}\text { Breusch-Pagan LM }\left(\mathrm{x}^{2}\right) \\
\text { (p) }\end{array}$ & \multicolumn{3}{|c|}{$\begin{array}{c}6.13 \\
(0.03)\end{array}$} & \\
\hline $\begin{array}{l}\text { Woolbridge test (F) } \\
\text { (p) }\end{array}$ & \multicolumn{3}{|c|}{$\begin{array}{l}56.64 \\
(0.00)\end{array}$} & \\
\hline \multicolumn{4}{|c|}{ Sargan test (p) } & 0.179 \\
\hline \multicolumn{4}{|c|}{ Arellano-Bond test AR(1) (p) } & 0.000 \\
\hline \multicolumn{4}{|c|}{ Arellano-Bond test AR(2) (p) } & 0.010 \\
\hline
\end{tabular}

Note: standard errors (se) and $p$-values are presented below their corresponding coefficient ( $s e ; p)$. Source: author's calculations. 
Age dependency ratio: The assessment of the relevance of a demographic factor (i.e. ratio of the number of people younger than 15 and older than 65 years of age over the total population - RELDEP) shows negative and statistically significant results (FGLS and OLS-PCSE estimators). This negative relationship between the variables is closely related to the life-cycle hypothesis where younger and older parts of the population save less. Partial confirmation of the impact of a demographic factor on the external imbalance probably reflects its (negative) influence on (private and public) domestic savings, which additionally confirms the validity of the twin deficit hypothesis in the region (see also Loayza et al., 2000). Moreover, such results are similar to the results of Bussière et al. (2004), Zanghieri (2004) and Herrmann and Jochem (2005).

\section{External Economic Conditions}

Openness: We find that the degree of openness (OPEN) of an economy is weakly negatively (but statistically insignificantly) related to its current account position. However, partial confirmation of the correlation is expressed by statistically significant estimates based on the FGLS and OLS-PCSE estimators. In fact, the openness variable could be indicative of attributes such as liberalized trade, receptiveness to technology transfers, and the ability to service external debt through export earnings (see MFR, 1996). Thus, transition countries with greater exposure to international trade tend to be more attractive to foreign capital. Further, the results indicate that external imbalances are significantly related to capital and financial account liberalization in the region. In any case, the results are similar to the conclusions of Chinn and Prasad (2003) for developing countries.

Real effective exchange rate: The relationship between the real exchange rate $(R E E R)$ and the current account deficit is positive and statistically significant, confirming the predictions of the Mundell-Fleming model. Indeed, real appreciation of the domestic currency by 10 per cent has the effect of reducing the current account balance by around 0.90 of a percentage point. The result is not a surprise since real appreciation reflects productivity gains in manufacturing (Balassa-Samuelson effect) as well as demand-side influences, such as the use of capital inflows and relatively high government spending to build up infrastructure. In addition, the result (not shown in Table 2) cannot confirm the appropriateness of the 'J-curve' in the region. Similar results have been found by Aristovnik in Zajc (2001), Calderon et al. (2002) and Herrmann and Jochem (2005).

Terms of trade: We find a positive and statistically significant relationship between the terms of trade (TOT) and current account balance, which is somewhat consistent with the Harberger-Lauresen-Metzler effect ${ }^{10)}$. In fact, an improvement of the terms of trade by 10 per cent leads to a current account deficit that is between 0.6-1.4 percentage points lower. Nevertheless, the decline in savings was not solely

10) The Harberger-Lauresen-Metzler effect predicts that positive transitory terms of trade shocks produce an improvement in current income that is greater than that in permanent income. Accordingly, an increase in savings follows and an improvement in current account positions emerges (see Obstfeld, 1982 and Mendoza, 1995). 
a result of adverse transitory terms of trade shocks but also a consequence of the poor economic state of these countries, especially in the first half of the 1990s. Similar results are found by Debelle in Faruqee (1996), Calderon et al. (2002) and Aristovnik (2002).

Table 2

Estimates of Regression Coefficients for Model (B) - 14 Transition Countries, (19922003) (Dependent Variable: CA)

\begin{tabular}{|c|c|c|c|c|}
\hline Explanatory Variables & $L S D V$ & FGLS & OLS-PCSE & $G M M-I V$ \\
\hline \multicolumn{5}{|l|}{ Persistency } \\
\hline$C A_{-I}$ & $\begin{array}{c}0.193 \\
(0.083 ; 0.02)\end{array}$ & $\begin{array}{c}0.424 \\
(0.067 ; 0.00)\end{array}$ & $\begin{array}{c}0.406 \\
(0.109 ; 0.00)\end{array}$ & $\begin{array}{c}0.191 \\
(0.091 ; 0.04)\end{array}$ \\
\hline \multicolumn{5}{|c|}{ Internal Economic Conditions } \\
\hline RELDEP (in logs) & $\begin{array}{c}0.043 \\
(0.133 ; 0.75)\end{array}$ & $\begin{array}{c}-0.180 \\
(0.056 ; 0.00)\end{array}$ & $\begin{array}{c}-0.158 \\
(0.058 ; 0.01)\end{array}$ & $\begin{array}{c}-0.370 \\
(0.290 ; 0.20)\end{array}$ \\
\hline GOVB & $\begin{array}{c}0.262 \\
(0.123 ; 0.04)\end{array}$ & $\begin{array}{c}0.292 \\
(0.067 ; 0.01)\end{array}$ & $\begin{array}{c}0.174 \\
(0.136 ; 0.20)\end{array}$ & $\begin{array}{c}0.256 \\
(0.134 ; 0.06)\end{array}$ \\
\hline \multicolumn{5}{|l|}{ External Sector } \\
\hline $\operatorname{REER}($ in $\log s)$ & $\begin{array}{c}-0.086 \\
(0.025 ; 0.00)\end{array}$ & $\begin{array}{c}-0.094 \\
(0.019 ; 0.00)\end{array}$ & $\begin{array}{c}-0.092 \\
(0.023 ; 0.00)\end{array}$ & $\begin{array}{c}-0.090 \\
(0.038 ; 0.02)\end{array}$ \\
\hline TOT (in logs) & $\begin{array}{c}0.057 \\
(0.029 ; 0.06)\end{array}$ & $\begin{array}{c}0.060 \\
(0.025 ; 0.02)\end{array}$ & $\begin{array}{c}0.057 \\
(0.028 ; 0.04)\end{array}$ & $\begin{array}{c}0.143 \\
(0.043 ; 0.00)\end{array}$ \\
\hline Adj. $R^{2}$ & 0.335 & & 0.455 & \\
\hline No. of Countries & 14 & 14 & 14 & 14 \\
\hline No. of obs. & 141 & 141 & 141 & 119 \\
\hline $\begin{array}{l}\text { Hausman test }\left(\mathrm{x}^{2}\right) \\
\text { (p) }\end{array}$ & \multicolumn{3}{|c|}{$\begin{array}{c}73.4 \\
(0.00)\end{array}$} & \\
\hline $\begin{array}{l}\text { Modified Wald test }\left(\mathrm{x}^{2}\right) \\
\text { (p) }\end{array}$ & \multicolumn{3}{|c|}{$\begin{array}{l}123.91 \\
(0.00)\end{array}$} & \\
\hline $\begin{array}{l}\text { Breusch-Pagan LM }\left(\mathbf{x}^{2}\right) \\
\text { (p) }\end{array}$ & \multicolumn{3}{|c|}{$\begin{array}{c}2.90 \\
(0.09)\end{array}$} & \\
\hline $\begin{array}{l}\text { Woolbridge test (F) } \\
\text { (p) }\end{array}$ & \multicolumn{3}{|c|}{$\begin{array}{l}67.61 \\
(0.00)\end{array}$} & \\
\hline \multicolumn{4}{|c|}{ Sargan test $(\mathbf{p})$} & 0.197 \\
\hline \multicolumn{4}{|c|}{ Arellano-Bond test AR(1) (p) } & 0.000 \\
\hline \multicolumn{4}{|c|}{ Arellano-Bond test $\mathrm{AR}(2)(p)$} & 0.367 \\
\hline
\end{tabular}

Note: standard errors $(s e)$ and $p$-values are presented below their corresponding coefficient $(s e ; p)$. Source: author's calculations. 
External debt: A country's current account deficit is likely to be effected by its stock of foreign assets. Nevertheless, the effect of the stock of debt on its flow (which is to a large extent given by the current account deficit) is a complex relationship marked by non-linearities, asymmetries, and threshold effects. Because of a lack of data, total external debt (EXTDEBT) can be used as an indicator of a country's net foreign asset position. We find a positive and statistically significant association between total (lagged) external debt and the current account balance. A onepercentage point rise in total external debt leads to about 0.02-0.04 of a percentage point rise in the current account balance (in the next year). However, one should not regard this relationship as a univocal reflection of the sole debt-cycle hypothesis. Indeed, many transition countries started their transition process with virtually no external debt, while some of them have accumulated sizable amounts of liabilities during the last decade. The results are in line with the previous findings of Doisy and Hervé (2003) and Zanghieri (2004).

\section{Evolution of the World Economy}

EU economic growth: An increase in the growth rate of the EU-15 (GDPG-EU) leads to a reduction in the current account deficits of transition countries. This can be explained by both a rise in the demand for transition country exports and the increased capital flows between developed countries at the expense of flows to transition countries. According to our estimates a one-percentage point rise in the growth rate of EU-15 countries would generate an improvement of between 0.75 and 1.25 percentage points in the current account balance. Indeed, the results are consistent with previous findings of MFR (1996) and Calderon et al. (2002).

On the basis of the determinants we simulate a historical benchmark for the current account positions to be compared to the actual current account balance (20002003 averages). In particular, we attempt to assess whether the actual current account positions among transition countries are consistent with the estimated ones. As there is generally no evidence of a possible downward bias of the LSDV estimator, we focus on estimates based on the (relatively more robust) LSDV estimator. Table 3 reports the actual and calculated positions which are implied by the value of models $A$ and $B$.

In fact, a number of important conclusions can be drawn from the following Table 3. First, the performance of the empirical models is good for most countries in the sample. This indicates that the models capture important elements to explain the current account positions for selected transition countries. Second, an important implication of the models is that the actual current account positions in most transition countries are recently (2000-03 period averages) not out of line with the fundamentals. Indeed, within the group of CEE countries only Estonia and Latvia with a current account deficit over 8 per cent of GDP show larger deficits than their estimated ones. On the other hand, it is relatively common to have excessive (negative) current account positions in the SEE region, such as in Albania, Bulgaria and Bosnia and Herzegovina. Even though most CIS countries have current account positions in line with the fundamentals, there are some exceptions, such as Georgia, Kazakhstan and Tajikistan. Moreover, the confirmation of substantial differences in the degree of convergence achieved so far and the economic fundamentals is pre- 
Table 3

Estimates of Current Account Deficits Excessiveness in Transition Countries (averages 2000-03)

\begin{tabular}{|c|c|c|c|}
\hline & $\begin{array}{c}\text { Estimated Actual CA } \\
\text { (average } 2000-03 \text { ) } \\
\text { model } A\end{array}$ & $\begin{array}{c}\text { Estimated CA } \\
\text { (average } 2000-03 \text { ) } \\
\text { model } B\end{array}$ & $\begin{array}{c}\text { CA } \\
\text { (average 2000-03) }\end{array}$ \\
\hline \multicolumn{4}{|l|}{$C E E$} \\
\hline Czech Republic & -7.7 & -6.0 & -5.9 \\
\hline Estonia & -6.3 & -7.1 & -8.8 \\
\hline Hungary & -9.3 & -7.8 & -7.7 \\
\hline Latvia & -5.3 & - & -8.4 \\
\hline Lithuania & -7.7 & -7.7 & -5.6 \\
\hline Poland & -4.5 & -4.1 & -3.4 \\
\hline Slovakia & -6.3 & -5.5 & -5.2 \\
\hline Slovenia & -0.9 & 0.0 & -0.2 \\
\hline \multicolumn{4}{|l|}{$S E E$} \\
\hline Albania & -4.4 & - & -6.6 \\
\hline Bulgaria & -3.9 & -3.3 & -6.6 \\
\hline $\begin{array}{l}\text { Bosnia and } \\
\text { Herzegovina }\end{array}$ & -15.2 & - & -16.0 \\
\hline Croatia & -6.8 & -6.7 & -5.5 \\
\hline Macedonia & -7.1 & -5.1 & -5.9 \\
\hline Romania & -5.3 & -4.7 & -4.6 \\
\hline \multicolumn{4}{|l|}{ CIS } \\
\hline Armenia & -11.5 & - & -9.8 \\
\hline Azerbaijan & -13.4 & - & -11.3 \\
\hline Belarus & -3.3 & - & -3.2 \\
\hline Georgia & -5.9 & - & -6.9 \\
\hline Kazakhstan & -0.2 & -0.5 & -1.1 \\
\hline Kyrgyzstan & -6.2 & - & -3.1 \\
\hline Moldavia & -7.9 & -8.4 & -7.4 \\
\hline Russia & 11.3 & 10.3 & 11.4 \\
\hline Tajikistan & -3.9 & - & -4.7 \\
\hline Turkmenistan & -8.4 & - & 6.3 \\
\hline Ukraine & 3.9 & - & 5.5 \\
\hline Uzbekistan & 1.0 & - & 1.7 \\
\hline
\end{tabular}

Note: (-) calculation is impossible due to a lack of data.

Source: Tables 1 and 2; author's calculations. 
sented by the relatively high external imbalances which are not seen as being excessive (for example in Azerbaijan (average deficit of 11.3 per cent of GDP), Armenia (9.8 per cent) and Hungary ( 7.7 per cent)). To sum up, there are generally no significant problems of excessive current account deficits in the region, with only a few countries recently exceeding estimated normal levels of external imbalance.

\section{Conclusions}

This article examines the main current account balance determinants in order to assess the potential excessiveness of current account deficits in selected transition countries. In this respect different estimators are presented and sensitivity tests are conducted, showing that the results are mostly robust across estimators and across countries. The results are chiefly consistent with the theoretical and previous empirical analysis and indicate that there is a moderate level of persisting current account deficits beyond what can be explained by the behaviour of its determinants. Economic growth has a negative effect on the current account balance, implying that the domestic growth rate is associated with a larger increase in domestic investment than savings. Moreover, the stages of development hypothesis can be confirmed since poorer countries in the region reveal higher current account deficits. Further, shocks in public budget rates are likely to be accompanied with a current account balance deterioration, confirming the validity of the twin deficit hypothesis in the region. The results also indicate the partial impact of demographic factors as well as the strong influence of the growth rate of EU-15 countries on the external imbalances. Finally, appreciation of the real exchange rate and a worsening of the terms of trade are generating a deterioration of the current account deficit in the transition region.

According to the simulated benchmark calculated on the basis of selected determinants, the results confirm that the actual current account balances are generally close to their estimated levels in the 2000-2003 period. In fact, this suggests that most transition countries are justified in running relatively high current account deficits. Indeed, the excessiveness problem could only be noticed in some less developed transition countries, such as Albania, Bulgaria, Latvia and Tajikistan. This notion is also in line with the intertemporal approach to the current account balance, suggesting that higher external deficits are a natural outcome when permanent domestic output exceeds the current one and when current investments and government consumption exceed their permanent levels. Nevertheless, when taking possible liquidity and solvency issues into account the current account excessiveness problem might be more widespread in the region. Moreover, for some CEE countries, despite their relatively high level of integration with world capital markets, large current account deficits can present a serious obstacle to further monetary integration. To conclude, since this article is one of the few papers to address these topics there remains much to study by way of extending and improving the presented analysis.

\section{APPENDIX A. VARIABLE DESCRIPTIONS AND DATA SOURCES}

The data used in this article were drawn from a number of different sources. Below we provide a list of the abbreviations (symbols) for the variables used in the analy- 
sis, a description of the variables and the source(s) from which the primary data used for constructing these variables were taken.

\begin{tabular}{|c|c|c|c|c|}
\hline VARIABLE & SYMBOL & DESCRIPTION & NOTE & SOURCE ${ }^{*}$ \\
\hline $\begin{array}{l}\text { Current account } \\
\text { balance }\end{array}$ & $\mathrm{CA}$ & $\begin{array}{l}\text { Current account } \\
\text { balance ( } \% \text { of GDP) }\end{array}$ & $\begin{array}{l}\text { positive (negative) } \\
\text { values indicate a } \\
\text { surplus (deficit) }\end{array}$ & $\begin{array}{l}E I U \\
E B R D \\
I F S\end{array}$ \\
\hline $\begin{array}{l}\text { Real economic } \\
\text { growth }\end{array}$ & GDPG & $\begin{array}{l}\text { Growth rate of real } \\
\text { GDP }(\%)\end{array}$ & & $W D I$ \\
\hline Relative income & RELY & $\begin{array}{l}\text { Income per capita } \\
\text { relative to income per } \\
\text { capita in the EU-15 } \\
\text { (in logs) }\end{array}$ & & $\begin{array}{l}\text { WDI } \\
\text { EUROSTAT }\end{array}$ \\
\hline $\begin{array}{l}\text { General government } \\
\text { budget balance }\end{array}$ & GOVB & $\begin{array}{l}\text { General government } \\
\text { budget balance }(\% \text { of } \\
\text { GDP) }\end{array}$ & $\begin{array}{l}\text { positive (negative) } \\
\text { values indicate a } \\
\text { surplus (deficit) }\end{array}$ & $E B R D$ \\
\hline $\begin{array}{l}\text { Age dependency } \\
\text { ratio }\end{array}$ & RELDEP & $\begin{array}{l}\text { Ratio of the number } \\
\text { of people younger } \\
\text { than } 15 \text { and older } \\
\text { than } 65 \text { years to } \\
\text { the total population } \\
\text { relative to the sample } \\
\text { average (in logs) }\end{array}$ & & $W D I$ \\
\hline Openness & OPEN & $\begin{array}{l}\text { Sum of exports and } \\
\text { imports of goods and } \\
\text { services }(\% \text { of GDP) }\end{array}$ & & WDI \\
\hline $\begin{array}{l}\text { Real effective } \\
\text { exchange rate }\end{array}$ & REER & $\begin{array}{l}\text { Real effective ex- } \\
\text { change rate index, } \\
\text { base year } 1997=100 \\
\text { (in logs) }\end{array}$ & $\begin{array}{l}\text { increase in index } \\
\text { denotes real } \\
\text { appreciation }\end{array}$ & EIU \\
\hline Terms of trade & TOT & $\begin{array}{l}\text { Changes in the rela- } \\
\text { tive prices of exports } \\
\text { and imports, base } \\
\text { year } 1997=100 \\
\text { (in logs) }\end{array}$ & & EIU \\
\hline External debt & EXTDEBT & $\begin{array}{l}\text { Gross external debt } \\
\text { (in \% GDP) }\end{array}$ & & $E B R D$ \\
\hline $\begin{array}{l}\text { Real economic } \\
\text { growth of the EU }\end{array}$ & GDPG-EU & $\begin{array}{l}\text { Growth rate of real } \\
\text { GDP in EU-15 (in \%) }\end{array}$ & & EUROSTAT \\
\hline \multicolumn{2}{|c|}{$\begin{array}{l}\text { COUNTRIES included in the sample } \\
(\operatorname{model} A)\end{array}$} & \multicolumn{3}{|c|}{$\begin{array}{l}\text { CEE - Czech R., Estonia, Hungary, Latvia, Lithuania, Poland, } \\
\text { Slovakia and Slovenia; SEE - Albania, Bosnia and Herzegovina, } \\
\text { Bulgaria, Croatia, Macedonia and Romania; CIS - Armenia, } \\
\text { Azerbaijan, Belarus, Georgia, Kazakhstan, Kyrgyzstan, Moldavia, } \\
\text { Russia, Tajikistan, Turkmenistan, Ukraine and Uzbekistan }\end{array}$} \\
\hline \multicolumn{2}{|c|}{$\begin{array}{l}\text { COUNTRIES included in the sample } \\
\text { (model B) }\end{array}$} & \multicolumn{3}{|c|}{$\begin{array}{l}\text { CEE - Czech R., Estonia, Hungary, Lithuania, Poland, Slovakia } \\
\text { and Slovenia; SEE - Bulgaria, Croatia, Macedonia and Romania; } \\
\text { CIS -Kazakhstan, Moldavia and Russia }\end{array}$} \\
\hline
\end{tabular}

*WDI - World Development Indicators (World Bank); EUROSTAT - EU database;

EBRD - Transition Report (different issues); IFS - International Financial Statistics (IFS). 


\section{APPENDIX B. \\ FIGURES AND TABLES}

Table 1

Private/Public Sector and Domestic Saving-Investment Imbalances in Transition Countries (in percentage of GDP; unweighted average)

\begin{tabular}{|c|c|c|c|c|c|c|c|c|c|}
\hline & \multicolumn{3}{|c|}{ Private sector balances } & \multicolumn{3}{|c|}{ Government sector balances } & \multicolumn{3}{|c|}{ Current account balance } \\
\hline & $\begin{array}{c}1992- \\
1997 \\
\text { average }\end{array}$ & $\begin{array}{c}1998- \\
2003 \\
\text { average }\end{array}$ & $\begin{array}{c}1992- \\
2003 \\
\text { average }\end{array}$ & $\begin{array}{c}1992- \\
1997 \\
\text { average }\end{array}$ & $\begin{array}{c}1998- \\
2003 \\
\text { average }\end{array}$ & $\begin{array}{c}1992- \\
2003 \\
\text { average }\end{array}$ & $\begin{array}{c}1992- \\
1997 \\
\text { average }\end{array}$ & $\begin{array}{c}1998- \\
2003 \\
\text { average }\end{array}$ & $\begin{array}{c}1992- \\
2003 \\
\text { average }\end{array}$ \\
\hline Czech Republic & -3.9 & -1.4 & -2.7 & 0.5 & -3.4 & -1.5 & -3.4 & -4.8 & -4.2 \\
\hline Estonia & -4.3 & -7.8 & -6.1 & -0.1 & -0.4 & -0.2 & -4.4 & -8.2 & -6.3 \\
\hline Hungary & -1.8 & -2.3 & -2 & -3.5 & -5.4 & -4.5 & -5.3 & -7.7 & -6.5 \\
\hline Latvia & 5.5 & -6.8 & -0.7 & -1.0 & -2.2 & -1.6 & 4.5 & -9.0 & -2.3 \\
\hline Lithuania & -2.7 & -3.9 & -3.4 & -4.1 & -3.6 & -3.8 & -6.8 & -7.5 & -7.2 \\
\hline Poland & 0.5 & -0.8 & -0.2 & -2.9 & -3.4 & -3.1 & -2.4 & -4.2 & -3.3 \\
\hline Slovakia & 0.6 & -2 & -0.8 & -4.1 & -4.0 & -4.0 & -3.5 & -6.0 & -4.8 \\
\hline Slovenia & 2.0 & 0.6 & 1.3 & 0.2 & -1.4 & -0.6 & 2.2 & -0.8 & 0.7 \\
\hline CEE & 0.0 & -3.0 & -1.5 & -1.8 & -3.0 & -2.4 & -1.8 & -6.0 & -3.9 \\
\hline Albania & -9.2 & 2.8 & -3.2 & -14.4 & -8.9 & -11.6 & -23.6 & -6.1 & -14.8 \\
\hline $\begin{array}{l}\text { Bosnia and } \\
\text { Herzegovina }\end{array}$ & -19 & -11 & -14 & -1.7 & -4.1 & -3.3 & -20.7 & -15.1 & -17.3 \\
\hline Bulgaria & 6.2 & -4.9 & 0.6 & -6.9 & -0.4 & -3.6 & -0.7 & -5.3 & -3.0 \\
\hline Croatia & -2.4 & -0.8 & -1.7 & -1.6 & -5.2 & -3.4 & -4.0 & -6.0 & -5.1 \\
\hline Macedonia & 0.8 & -3 & -1.1 & -4.8 & -2.4 & -3.6 & -4.0 & -5.4 & -4.7 \\
\hline Romania & -2.0 & -1.3 & -1.6 & -3.4 & -3.5 & -3.5 & -5.4 & -4.8 & -5.1 \\
\hline $\begin{array}{l}\text { Serbia and } \\
\text { Montenegro }\end{array}$ & n. a. & -4.4 & -4.8 & n. a. & -2.6 & -2.6 & -8.0 & -7.0 & -7.4 \\
\hline SEE & -3.9 & -3.2 & -3.6 & -5.9 & -3.9 & -4.9 & -9.8 & -7.1 & -8.5 \\
\hline Armenia & 1.4 & -8.9 & -3.6 & -18.1 & -4.0 & -11.0 & -16.7 & -12.9 & -14.6 \\
\hline Azerbaijan & -13.8 & -12.9 & -12.9 & -6.0 & -1.9 & -3.9 & -19.8 & -14.8 & -16.8 \\
\hline Belarus & -3.8 & -2.1 & -2.8 & -3.2 & -1.4 & -2.3 & -7.0 & -3.5 & -5.1 \\
\hline Georgia & -7.4 & -3.6 & -5.6 & -13.1 & -3.8 & -8.4 & -20.5 & -7.4 & -14.0 \\
\hline Kazakhstan & -4.3 & -0.2 & -2.2 & -4.9 & -1.6 & -3.3 & -9.2 & -1.8 & -5.5 \\
\hline Kyrgyzstan & -4.3 & -0.2 & -1.7 & -9.3 & -8.0 & -8.7 & -13.6 & -8.2 & -10.4 \\
\hline Moldavia & 1.0 & -8.2 & -3.7 & -10.2 & -1.1 & -5.6 & -9.2 & -9.3 & -9.3 \\
\hline Russia & 10.2 & 9.1 & 9.7 & -7.4 & 0.6 & -3.4 & 2.8 & 9.7 & 6.3 \\
\hline Tajikistan & -3.5 & -4.1 & -3.3 & -11.8 & -1.1 & -6.5 & -15.3 & -5.2 & -9.8 \\
\hline Turkmenistan & 13.5 & -6 & 3.8 & -3.1 & -0.9 & -2.0 & 10.4 & -6.9 & 1.8 \\
\hline Ukraine & 8.3 & 4.5 & 7 & -11.2 & -0.5 & -5.8 & -2.9 & 4.0 & 1.2 \\
\hline Uzbekistan & 4.0 & 2.3 & 3.3 & -7.6 & -1.4 & -4.5 & -3.6 & 0.9 & -1.2 \\
\hline CIS & 1.3 & -2.5 & -0.6 & -8.8 & -2.1 & -5.5 & -7.5 & -4.6 & -6.1 \\
\hline $\begin{array}{l}\text { ALL TRANSITION } \\
\text { COUNTRIES }\end{array}$ & -0.9 & -2.9 & -1.9 & -5.5 & -3.0 & -4.3 & -6.4 & -5.9 & -6.2 \\
\hline
\end{tabular}

Sources: WDI (2004), EIU (2004), EBRD (2004), author's calculations. 
Table 2

Determinants of Current Account Deficits

\begin{tabular}{|c|c|c|}
\hline Variable & $\begin{array}{l}\text { Theoretically } \\
\text { Expected Sign }\end{array}$ & Empirical Sign And Sources \\
\hline Persistency & + & $\begin{array}{l}+ \\
\text { Debelle and Faruqee (1996), Reisen (1998), Calderon et al. } \\
\text { (2002), Chinn and Prasad (2003), Zanghieri (2004), Bussière } \\
\text { et al. (2004), Herrmann and Jochem (2005) }\end{array}$ \\
\hline \multicolumn{3}{|c|}{ Internal Economic Conditions } \\
\hline \multirow[t]{3}{*}{ Growth Rate } & + & $\begin{array}{l}+ \\
\text { MFR (1996, 1998), Aristovnik and Zajc (2001), Aristovnik } \\
(2002), \text { IMF (2005) }\end{array}$ \\
\hline & $\begin{array}{l}\text { Local productivity } \\
\text { shock (temporary/ } \\
\text { permanent): } \\
+/-\end{array}$ & $\begin{array}{l}+ \\
\text { Glick and Rogoff (1995), Razin (1995), Reisen (1998) }\end{array}$ \\
\hline & $\begin{array}{l}\text { Global productivity } \\
\text { shock (temporary/ } \\
\text { permanent): } \\
+/ 0\end{array}$ & $\begin{array}{l}0 \\
\text { Reisen (1998) }\end{array}$ \\
\hline Relative income & - & $\begin{array}{l}\text { - } \\
\text { Backus et al. (1994), Chinn and Prasad (2003), Bussière et al. } \\
\text { (2004), Herrmann and Jochem (2005) }\end{array}$ \\
\hline Investments & + & $\begin{array}{l}+ \\
\text { Glick and Rogoff (1995), Debelle and Faruqee (1996), Reisen } \\
\text { (1998), Bussière et al. (2004), Herrmann and Jochem (2005) }\end{array}$ \\
\hline Savings & - & - Calderon, et al. (2002), Aristovnik (2002) \\
\hline Demographics & + & $\begin{array}{l}\text { - } \\
\text { Doisy and Hervé (2003), IMF (2005) }\end{array}$ \\
\hline Fiscal policy & + & $\begin{array}{l}+ \\
\text { Debelle and Faruqee (1996), Aristovnik and Zajc (2001), Doisy } \\
\text { and Hervé (2003), Zanghieri (2004), Bussière et al. (2004), } \\
\text { Herrmann and Jochem (2005), Duczynski (2005), IMF (2005) }\end{array}$ \\
\hline \multicolumn{3}{|l|}{ External Sector } \\
\hline Degree of Openness & $+/-$ & $\begin{array}{l}- \\
\text { MFR (1996, 1998), Calderon, et al. (2002), Aristovnik (2002), } \\
\text { Chinn and Prasad (2003), Doisy and Hervé (2003), Duczynski } \\
(2005)\end{array}$ \\
\hline $\begin{array}{l}\text { Real Effective } \\
\text { Exchange Rate }\end{array}$ & $\begin{array}{l}\text { Marshall-Lerner } \\
\text { effect: }+\end{array}$ & $\begin{array}{l}\text { + Debelle \& Faruqee (1996), Aristovnik and Zajc (2001), } \\
\text { Calderon, et al. (2002), Herrmann and Jochem (2005) }\end{array}$ \\
\hline
\end{tabular}




\begin{tabular}{|c|c|c|}
\hline Variable & $\begin{array}{l}\text { Theoretically } \\
\text { Expected Sign }\end{array}$ & Empirical Sign And Sources \\
\hline \multirow[t]{2}{*}{ Terms of Trade } & $\begin{array}{l}\text { Harberger-Laursen- } \\
\text { Metzler effect: - }\end{array}$ & $\begin{array}{l}\text { - } \\
\text { Razin (1995), Debelle \& Faruqee (1996), Reisen (1998), Iscan } \\
\text { (1998), Calderon, et al. (2002), Duncan (2003), IMF (2005) }\end{array}$ \\
\hline & $+/-$ & $\begin{array}{l}\text { J-krivulja: Tornell and Lane (1994), Serven (1999) S-krivulja: } \\
\text { Senhadji (1998) }\end{array}$ \\
\hline Net Foreign Assets & $+/-$ & $\begin{array}{l}+/- \\
\text { Calderon, et al. (2002), Chinn and Prasad (2003) } \\
+ \\
\text { Aristovnik (2002) }\end{array}$ \\
\hline \multicolumn{3}{|c|}{ Evolution of the World Economy } \\
\hline $\begin{array}{l}\text { Developed Countries } \\
\text { Growth Rate }\end{array}$ & - & MFR (1996, 1998), Calderon, et al. (2002) \\
\hline $\begin{array}{l}\text { World Real } \\
\text { Interest Rate }\end{array}$ & $\begin{array}{l}\text { Net Creditor: + } \\
\text { Net Debtor: - }\end{array}$ & $\begin{array}{l}0 \\
\text { Reisen (1998) } \\
- \\
\text { Calderon, et al. (2002) }\end{array}$ \\
\hline
\end{tabular}

Note: + deficit increase; - deficit decrease.

Table 3

\section{Current Account Determinants: Descriptive Statistics - 26 Transtion Countries (Annual Data, 1992-2003)}

\begin{tabular}{|c|c|c|c|c|c|}
\hline Variables & No. of obs. & Mean & Std. Dev. & Minimum & Maximum \\
\hline Current account balance (CA) & 306 & -0.06109 & 0.10104 & -0.685 & 0.685 \\
\hline \multicolumn{6}{|l|}{ Internal Economic Conditions } \\
\hline Real economic growth (GDPG) & 316 & 0.13237 & 0.10598 & -0.449 & 0.859 \\
\hline Relative income (RELY)* & 308 & -1.65895 & 0.76872 & -3.5367 & -0.43510 \\
\hline Budget balance (GOVB) & 313 & -0.43633 & 0.57040 & -0.547 & 0.031 \\
\hline Age dependency (RELDEP) ${ }^{*}$ & 324 & -0.01522 & 0.16856 & -0.26084 & 0.45929 \\
\hline \multicolumn{6}{|l|}{ External Sector } \\
\hline Openness (OPEN) & 307 & 0.97035 & 0.33169 & 0.35962 & 1.91352 \\
\hline Real effective exchange rate (REER) ${ }^{*}$ & 181 & 4.517367 & 0.3199754 & 2.375557 & 4.96783 \\
\hline Terms of trade (TOT) ${ }^{*}$ & 172 & 4.60747 & 0.1199813 & 4.279915 & 5.05745 \\
\hline External debt (EXTDEBT) & 302 & 0.49427 & 0.31451 & 0.040 & 1.92878 \\
\hline \multicolumn{6}{|l|}{ External Sector } \\
\hline EU real economic growth (GDPG-EU) & 12 & 0.01875 & 0.01117 & -0.004 & 0.036 \\
\hline
\end{tabular}

Note: ${ }^{*}$ in $\log s$.

Source: author's calculations. 
Table 4

Simple Correlation Matrix of Current Account Determinats: 26 transtion countries (model A) (annual data, 1992-2003)

\begin{tabular}{|c|c|c|c|c|c|c|c|}
\hline & $\overline{\mathbf{C A}_{-1}}$ & GDPG & RELY* $^{*}$ & GOVB & OPEN & $\begin{array}{c}\text { EXT- } \\
\text { DEBT }_{-1}\end{array}$ & GDPG-EU \\
\hline $\mathrm{CA}_{-1}$ & 1.00 & & & & & & \\
\hline GDPG & -0.11 & 1.00 & & & & & \\
\hline RELY* & 0.30 & 0.01 & 1.00 & & & & \\
\hline GOVB & 0.44 & 0.25 & 0.24 & 1.00 & & & \\
\hline OPEN & -0.03 & -0.02 & 0.18 & 0.26 & 1.00 & & \\
\hline EXTDEBT $_{-1}$ & -0.23 & 0.30 & -0.22 & -0.11 & 0.15 & 1.00 & \\
\hline GDPG-EU & -0.09 & 0.02 & -0.07 & 0.02 & -0.04 & -0.06 & 1.00 \\
\hline
\end{tabular}

Note: ${ }^{*}$ in logs.

Source: author's calculations.

Table 5

Simple Correlation Matrix of Current Account Determinats: 14 transtion countries (model B) (annual data, 1992-2003)

\begin{tabular}{|l|c|c|c|c|c|c|}
\hline & CA $_{-1}$ & GOVB & RELDEP & OPEN & REER $^{*}$ & TOT $^{*}$ \\
\hline CA $_{-1}$ & 1.00 & & & & & \\
\hline GOVB & 0.29 & 1.00 & & & & \\
\hline RELDEP & -0.38 & -0.18 & 1.00 & & & \\
\hline OPEN & -0.34 & 0.16 & 0.05 & 1.00 & & \\
\hline REER $^{*}$ & -0.33 & 0.01 & -0.04 & 0.17 & 1.00 & \\
\hline TOT $^{*}$ & 0.01 & 0.09 & 0.07 & 0.01 & 0.30 & 1.00 \\
\hline
\end{tabular}

Note: ${ }^{*}$ in logs.

Source: author's calculations. 


\section{References}

Abell, A. B., Bernanke, B. S. (2001), Macroeconomics, 4th Ed. Boston: Addison Wesley Longman.

Adedeji, O. S. (2001), "The Size and Sustainability of Nigerian Current Account Deficits". IMF Working Paper No. 01/87.

Arellano, M., Bond, S. (1991), Some Tests of Specification for Panel Data: Monte Carlo Evidence and an Application to Employment Equations. Review of Economic Studies, 58, pp. 277-297.

Arellano, M., Bover, O. (1995), Another Look at the Instrumental Variable Estimation of ErrorComponents Models. Journal of Econometrics, 68 (1), pp. 29-51.

Aristovnik, A., Zajc, K. (2001), "Current Account Performance and Fiscal Policy: Evidence on the Twin Deficits in Central and Eastern Europe", in Economics of Transition: Theory, Experience and EU Enlargement. INFER, Berlin, 7-8 September, pp. 121-140.

Aristovnik, A. (2002), What Determines the Current Account Balances in Central and Eastern Europe? Naše gospodarstvo (Our Economy), 48 (5/6), pp. 450-467.

Bond, S. (2002), "Dynamic Panel Data Models: A Guide to Micro Data Methods and Practices". Cemmap Working Paper No. 09/02.

Beck, N., Katz, J. N. (1996), Nuisance vs. Substance: Specifying and Estimating Time-SeriesCross Models. Political Analysis, 6, pp. 1-36.

Bussière, M., Fratzscher, M., Müller, G. J. (2004), "Current Account Dynamics in OECD and EU Acceding Countries - an Intertemporal Approach". EIB, Luxembourg, EIB Working Paper Series No. 311.

Calderon, C., Chong, A., Loayza, N. (2002), Determinants of Current Account Deficits in Developing Countries. Contributions to Macroeconomics, 2, pp. 1-35.

Campbell, J. Y. (1987), Does Saving Anticipate Declining Labor Income? An Alternative Test of the Permanent Income Hypothesis. Econometrica, 55 (6), pp. 1249-1273.

Chen, X., Lin, S., Reed, R. W. (2005), "Another Look at What to Do with Time-Series CrossSection Data". Economics Working Paper Archive at WUSTL, No. 0506004.

Chinn, M., Prasad, E. S. (2003), Medium-Term Determinants of Current Accounts in Industrial and Developing Countries: An Empirical Exploration. Journal of International Economics, Elsevier, 59 (1), pp. 47-76.

Coricelli, F., Jazbec, B. (2001), "Real Exchange Rate Dynamics in Transition Economies". CEPR Discussion Papers No. 2869.

Corsetti, G., Pesenti, P., Roubini, N. (1998), "What Caused the Asian Currency and Financial Crisis? Part I: A Macroeconomic Overview". NBER Working Paper No. 6833.

Debelle, G., Faruqee, H. (1996), "What Determines the Current Account? A Cross-Sectional and Panel Approach". IMF Working Paper No. 58.

Doisy, H., Hervé, K. (2003), Les implication des deficits ciurants des PECO. Economies Internationale, 95, pp. 59-88.

Duczynski, P. (2005), Long-Run Current Account Deficits in Transition Economies. Eastern European Economics, 43 (3), pp. 21-54.

ECB (2004), Convergence Report 2004. Frankfurt: ECB.

Edwards, S. (2001), “Does the Current Account Matter?” NBER Working Paper No. 8275. (2004), "Thirty Years of Current Account Imbalances, Current Account Reversals and Sudden Stops". NBER Working Paper No. 10276.

Gandolfo, G. (2004), Elements of International Economics. Berlin: Springer-Verlag. 
Glick R., Rogoff K. (1995), Global versus Country-Specific Productivity Shocks and the Current Account. Journal of Monetary Economics, 35.

Herrmann, S., Jochem, A. (2005), "Determinants of Current Account Developments in Central and Eastern European EU Member States -Consequences for Enlargement of the Euro Area". Deutsche Bundesbank Discussion Paper No. 32.

Holman, J. A. (2001), Is the Large US Current Account Deficit Sustainable? Federal Reserve Bank of Kansas City Economic Review, 86 (1), pp. 5-23.

IMF (2005), World Economic Outlook. Washington: IMF, April 2005.

Isard, P., Faruquee, H., Kimcaid, R. G., Fetherston, M. (2001), "Methodology for Current Account and Exchange Rate Assessments". IMF Occasional Paper No. 209.

Iscan, T. B. (2000), The Terms of Trade, Productivity Growth, and the Current Account. Journal of Monetary Economics, 45.

Kamin, S. B., Schindler, J. W., Shawna, S. L. (2001), "The Contribution of Domestic and External Factors to Emerging Market Devaluation Crisis: An Early Warning System Approach". FBR International Finance Discussion Paper No. 711.

Kiviet, J. (1995), "On Bias, Inconsistency and Efficiency of Various Estimators in Dynamic Panel Data Models. Journal Econometrics, 68 (1), pp. 53-78.

Kydland, F., Prescott, E. (1990), Business Cycles: Real Facts and a Monetary Myth. Federal Reserve Bank of Minneapolis Quarterly Review, Spring, pp. 3-18.

Loayza, N., Schmidt-Hebbel, K., Serven, L. (2000), "What Drives Private Saving Around the World?" WB Working Paper.

Mankiw, G. N. (2003), Macroeconomics, 5th Ed. New York: Worth Publishers.

Megarbane, P. (2002), "Slovakia's External Current Account Deficit: Why So Large and Is It Sustainable?" Country Report No. 02/210.

Mendoza, E. G. (1995), The Terms of Trade, the Real Exchange Rate, and Economic Fluctuations. International Economic Review, 36 (1), pp. 101-37.

Milesi-Ferretti, G. M., Razin, A. (1998), "Current Account Reversals and Currency Crises: Empirical Regularities". NBER Working Papers No. 6620.

NBER Working Paper No. 5467. (1996), "Sustainability of Persistent Current Account Deficits".

Miller, N. C. (2002), Balance of Payments and Exchange Rate Theories. Cheltenham: Edward Elgar Publishing Ltd.

Nason, J. M., Rogers, J. H. (2003), 'The Present-Value Model of the Current Account Has Been Rejected: Round up the Usual Suspects". Federal Reserve Bank of Atlanta Working Paper No. 7.

Obstfeld, M. (1982), Aggregate Spending and the Terms of Trade: Is There a Laursen-Metzler Effect? Quarterly Journal of Economics, 97, pp. 251-70.

Obstfeld, M., Rogoff, K. (1996), Foundations of International Macroeconomics. Cambridge, MA: MIT Press.

(2000), "Perspectives on OECD Economic Integration: Implications for US Current Account Adjustment". CIDER Working Papers, C00-116.

Pérez, G. F., Cuñado, J. (2001), "Intertemporal Current Account and Productivity Shocks: Evidence for Some European Countries". Working Papers on International Economics and Finance No. 05.

Radelet, S., Sachs, J. (2000), "The Onset of the East Asian Currency Crisis". NBER Working Paper No. 6680. 
Razin, A. (1995), "The Dynamic-Optimizing Approach to the Current Account: Theory and Evidence", in Understanding Interdependence: The Macroeconomics of the Open Economy.

Reisen, H. (1998), "Sustainable and Excessive Current Account Deficits". OECD Technical Papers No. 132.

Roubini, N., Wachtel, P. (1999), "Current-Account Sustainability in Transition Economies," in Balance of Payments, Exchange Rates, and Competitiveness in Transition Economies, Kluwer Academic Publishers, pp. 19-93.

Sachs, J. D. (1981), The Current Account and Macroeconomic Adjustment in the 1970s. Brookings Papers on Economic Activity, No. 1.

Senhadji, A. S. (1998), Dynamics of the Trade Balance and the Terms of Trade in LDCs: The SCurve. Journal of International Economics, 46, pp. 105-131.

Servén, L. (1999), Terms-of-Trade Shocks and Optimal Investment: Another Look at the LaursenMetzler Effect. Journal of International Money and Finance, 18, pp. 337-365.

Summers, L. H. (2000), International Financial Crises: Causes, Prevention, and Cures. American Economic Review, 90 (2), pp. 12-28.

Svensson, L., Razin, A. (1983), The Terms of Trade and the Current Account: The HarbergerLaursen-Metzler Effect. Journal of Political Economy, 91 (1), pp. 97-125.

Tornell, A., Lane, P. (1994), "Are Windfalls a Curse? A Non-Representative Agent Model of the Current Account and Fiscal Policy", NBER Working Paper No. 4839.

Zanghieri, P. (2004), "Current Account Dynamics in New EU Members". CEPII Working Paper No. 2004-07. 